\title{
Clinical characteristics associated with the finding of thyroid cancer originating from hot nodules in patients with hyperthyroidism: a case report and systematic review of the literature
}

\author{
Características clínicas asociadas al hallazgo de cáncer de tiroides \\ originado a partir de nódulos calientes en pacientes con hipertiroidismo: \\ reporte de un caso y revisión sistemática de la literatura
}

\author{
Carlos Osorio ${ }^{1}$, Jorge Ballestas², Diego Barrios ${ }^{3}$, Andrés Arévalo $^{3}$, Shekyna Montaño ${ }^{3}$, \\ Nashelly Pérez ${ }^{3}$, Yessica Guardo ${ }^{3}$, Hernán Oviedo ${ }^{3}$, Valeria Zambrano ${ }^{3}$, Katherine Redondo ${ }^{4}$, \\ Francisco Herrera ${ }^{1}$
}

1 Scalpellum Research Group. Professor, School of Medicine, Universidad de Cartagena, Cartagena, Colombia. Endocrine Surgery Group, General Surgery Service, E.S.E. Hospital Universitario del Caribe, Cartagena, Colombia.

2 Scalpellum Research Group. General Surgery Resident, School of Medicine, Universidad de Cartagena, Cartagena, Colombia.

3 Scalpellum Research Seedbed. Ungraduated Student, School of Medicine, Universidad de Cartagena, Cartagena, Colombia. E.S.E. Hospital Universitario del Caribe, Cartagena, Colombia.

4 Scalpellum Research Group. Professor, School of Medicine, Universidad de Cartagena, Cartagena, Colombia. Pathological Anatomy Service, E.S.E. Hospital Universitario del Caribe, Cartagena, Colombia.

\begin{abstract}
Coexistence between thyroid cancer and hyperthyroidism is rare, and most of the nodular lesions from which a malignant tumor is documented in this group of patients correspond to cold nodules. Justified by the increasing number of reports in the literature about malignant tumors diagnosed from hot nodules, a systematic review was carried out to determine possible factors associated with the diagnosis of thyroid cancer from hot nodules in patients with hyperthyroidism. The results suggest that the clinical diagnosis of toxic nodular goiter, nodular lesions of diameter $>10 \mathrm{~mm}$ and a histological type compatible with a follicular carcinoma, are factors that on their own increase the risk of making the diagnosis of cancer from a hot nodule.
\end{abstract}

Keywords: thyroid gland; thyroid neoplasms; hyperthyroidism; thyroid nodule; adenocarcinoma, follicular; systematic review.

\footnotetext{
Received: 01/13/2021 - Accepted: 01/24/2021 - On line: 11/06/2021

Corresponing autor: Carlos Gustavo Osorio Covo Address: E.S.E. Hospital Universitario del Caribe, Zaragocilla, 29 Street N 50 - 50 , Cartagena, Colombia. Phone number: +573194988374. Email: cosorioc@gruposcalpellum.com

Cite as: Osorio C, Ballestas J, Barrios D, Arévalo A, Montaño S, Pérez N, Guardo Y, Oviedo H, Zambrano V, Redondo K, Herrera F. Clinical characteristics associated with the finding of thyroid cancer originating from hot nodules in patients with hyperthyroidism: a case report and systematic review of the literature. Rev Colomb Cir. 2021;36:682-95. https://doi.org/10.30944/20117582.790

This is an open access article under Creative Commons License - BY-NC-ND https://creativecommons.org/licenses/by-nc-nd/4.0/deed.es
} 


\section{Resumen}

La coexistencia entre cáncer de tiroides e hipertiroidismo es infrecuente, y la mayoría de las lesiones nodulares a partir de las cuales se documenta un tumor maligno en este grupo de pacientes corresponden a nódulos fríos. Justificado en el creciente número de reportes en la literatura acerca de tumores malignos diagnosticados a partir de nódulos calientes, se realizó una revisión sistemática que tuvo como objetivo determinar los posibles factores asociados con el diagnóstico de cáncer de tiroides a partir de nódulos calientes en pacientes con hipertiroidismo. Los resultados sugieren que el diagnóstico clínico de bocio nodular tóxico, lesiones nodulares de diámetro mayor de $10 \mathrm{~mm}$ y tipo histológico compatible con carcinoma folicular, son factores que aumentan por sí solos el riesgo de realizar el diagnóstico de cáncer a partir de un nódulo caliente.

Palabras clave: glándula tiroides; neoplasias de la tiroides; hipertiroidismo; nódulo tiroideo; adenocarcinoma folicular; revisión sistemática.

\section{Introduction}

A hot thyroid nodule is defined as an image that concentrates large amounts of a radiotracer compared to other nodules or the rest of the thyroid parenchyma, and is seen as a "hot spot" during the gamma study of a patient with hyperthyroidism ${ }^{1}$. Coexistence between thyroid cancer and hyperthyroidism is rare, as most of the hot nodules in patients with hyperthyroidism are considered benign; however, there is evidence suggesting an increasing number of documented cases of thyroid cancer in patients with toxic nodular goiter, toxic multinodular goiter, and toxic diffuse goiter, with no certain prevalence known at this time ${ }^{2}$. Most of these lesions are described as non-functional nodules adjacent to hot nodules or immersed in glands with diffuse tracer uptake, for example, cold nodules. However, there are some reports in the literature that inform the development of cancer from hot nodules in patients with hyperthyroidism, which forces us to preoperatively rule out the presence of cancer ${ }^{3}$. Unfortunately, there are no reports in the national literature that describe the development of cancer from hot thyroid nodules. In addition to documenting a relevant clinical case, the objective of this systematic review is to determine the possible clinical characteristics associated with the finding of thyroid cancer originating from hot nodules in patients with hyperthyroidism.

\section{Case presentation}

A 38-year-old female patient consulted for symptoms of at least 6 months of evolution consisting of palpitations, distal tremor in upper limbs and unconscious weight loss. On physical examination, a left lobe-dependent grade I goiter was documented, associated with 15 points on the Burch-Wartofsky Scale, consistent with a low probability of developing a thyroid storm. She presented with serum TSH levels demonstrating suppression and an ultrasound that reported a thyroid gland of heterogeneous ecogenicity and asymmetric lobar volumes, due to a hypoecogenic, partially defined borderline nodular image measuring $15 \mathrm{~mm} \times 15 \mathrm{~mm}$ in relation to a thyroid nodule located in the left lobe, compatible with TIRADS category 4 . No medical therapy was started because the patient referred that during the initial assessment done by endocrinology, she begun treatment with central and peripheral thyroid blockade, and presented allergic reaction to this medication. She is referred to the Endocrine Surgery Service of the E.S.E. Hospital Universitario del Caribe due to the impossibility of carrying out medical treatment.

After our assessment, a clinical impression of a toxic nodular goiter was made and a complete thyroid profile is requested, including antithyroid antibodies, thyroid scan and fine needle biopsy under ultrasound guidance of the nodular lesion, to define the etiological diagnosis of hyperthyroidism and indication of surgical management. Thyroid profile results were compatible with clinical hyperthyroidism, with levels of TSH $0.004 \mathrm{uUI} / \mathrm{ml}$, total T4 of $12 \mathrm{ng} / \mathrm{ml}$, free $\mathrm{T} 4$ of $1.67 \mathrm{ng} / \mathrm{dl}$, free $\mathrm{T} 3$ of $3.98 \mathrm{pb} / \mathrm{ml}$ and total T3 of $1.1 \mathrm{pb} / \mathrm{ml}$, presenting antibodies anti 
peroxidase thyroid $10 \mathrm{mg} / \mathrm{dl}$ and antithyroglobulin $20 \mathrm{mg} / \mathrm{dl}$. The results of the thyroid scan showed an increased uptake in the middle third of the left thyroid lobe, which suppressed the rest of the parenchyma, with a capture index of 8.1 (Figure 1).

Evaluation of the cytological smears obtained by fine needle biopsy showed findings conclusive with malignancy, category VI of the Bethesda

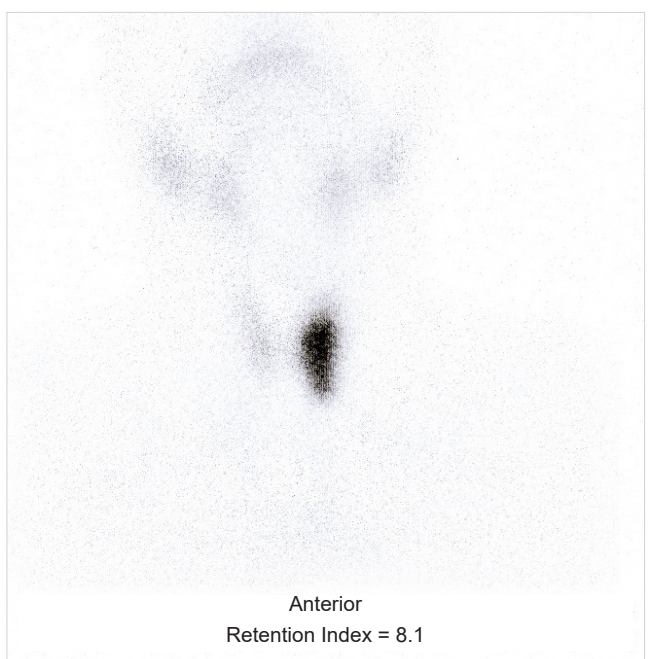

Image 1. Tc99 thyroid scintigraphy showing a hot nodule located in the left thyroid lobe, which suppresses tracer uptake in the rest of the thyroid parenchyma.
System (Figure 2). This result documented the diagnosis of a toxic nodular goiter, secondary to Cope's disease with an uncertain behaving tumor of the thyroid gland. In view of a cytology suggestive of malignancy, a contrasted neck scan is requested and it documented images with heterogeneous capture of contrast material in pre-tracheal station and left paratracheal station of $10 \mathrm{~mm}$ and $15 \mathrm{~mm}$, respectively, without evidence of suggestive images of adenomegaly in lateral stations.

Therefore, the patient is encouraged to have a total thyroidectomy with central neck lymphadenectomy. The macroscopic study of the surgical specimen showed a thyroid gland weighing 10 grams, in which a single nodule was observed, located in the middle third of the left lobe, pearly white in color and with a spiculated and irregular contour, which did not appear to be encapsulated; the rest of the parenchyma was of usual appearance (Figure 3). The microscopic study of the surgical specimen was compatible with an infiltrating non-encapsulated papillary carcinoma of follicular variant, associated with low-volume lymph node metastasis, represented by 2 of 8 nodes involved by the tumor lesion (Figure 4 ). The definitive diagnosis was a toxic nodular goiter secondary to a malignant tumor of the thyroid gland.
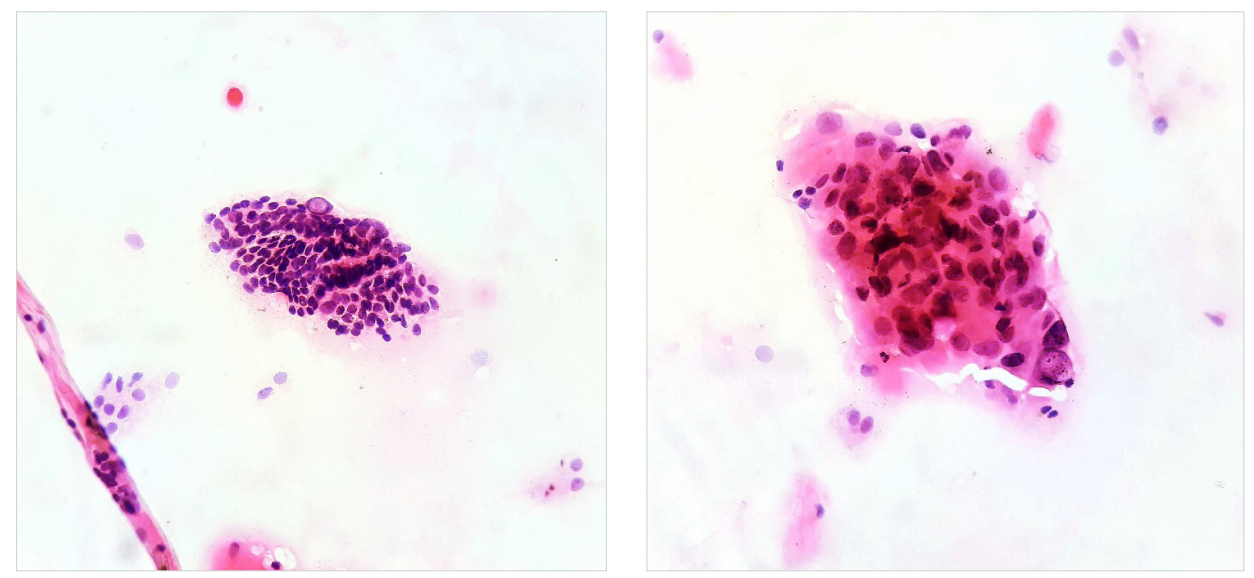

Image 2. Left,10x magnification. Groups of follicular cells with nuclear crowding are recognized, forming macrofollicles and microfollicles, some of the cells show intranuclear inclusions; Right, 40x magnification. A group of follicular cells with the presence of clefts, intranuclear inclusions, anisonucleosis and hyperchromasia is recognized. 


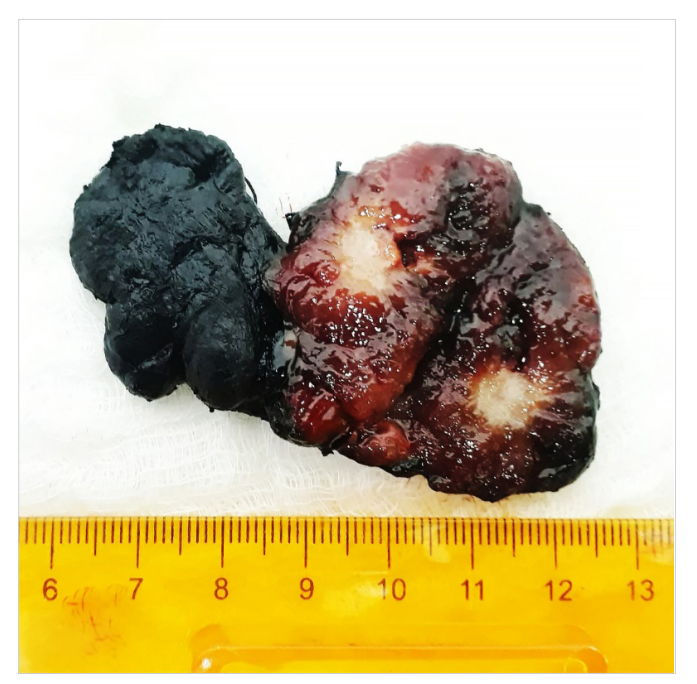

Image 3. Surface stained with India ink. A surgical specimen corresponding to the product of a total thyroidectomy weighing 10 grams is recognized. In the longitudinal section of the left lobe is recognized a poorly defined nodule, firm on palpation, pearly white in color and irregular contour with a starry appearance. Rest of the parenchyma of usual appearance.

\section{Systematic review methodology}

The systematic review process was standarized according to the parameters established in The PRISMA statement ${ }^{4}$ and the systematization was carried out with the implementation of the Software Review Manager 5.3.

Articles published in English were searched in the Excerpta Medica database - Embase and Medline from January 1, 2001 to June 30, 2020, using the following terms: "thyroid cancer" OR "thyroid carcinoma" OR "papillary thyroid carcinoma" OR "papillary carcinoma” AND "hyperthyroidism" OR "thyrotoxicosis".

A study was considered as one that addressed the core topic when in its title or in its structured abstract the relationship between thyroid cancer and hyperthyroidism was implicit. The inclusion criteria were: 1 . The subject of study had to be defined as a surgical specimen; 2 . The patient to whom the surgical specimen corresponds has been diagnosed with hyperthyroidism prior to the surgical procedure; 3 . The diagnosis of hyperthyroidism was confirmed biochemically and
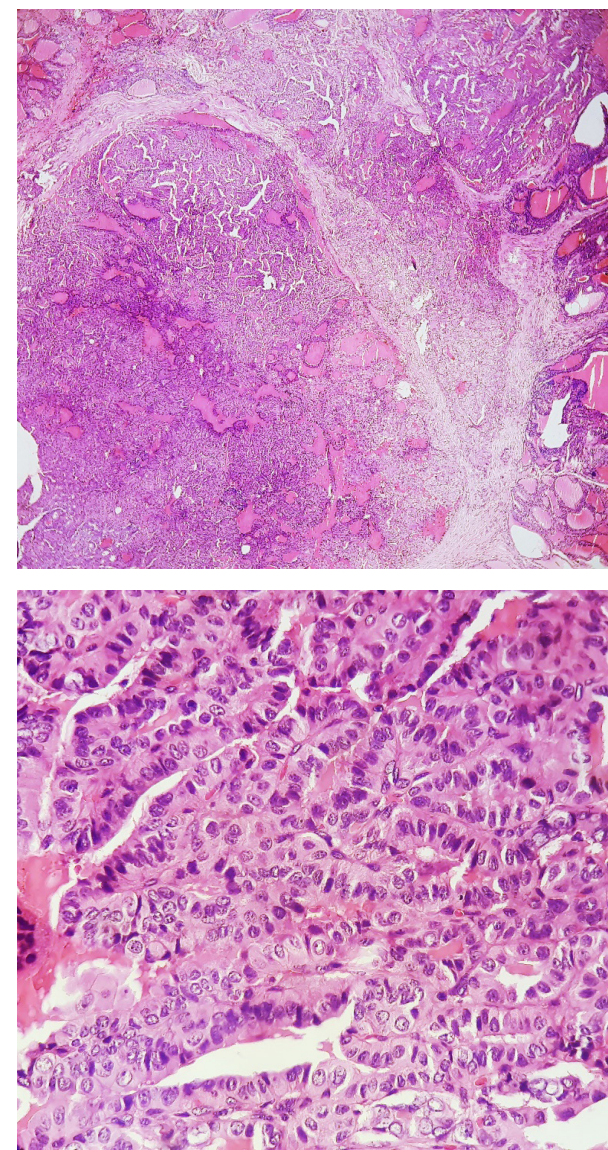

Image 4. Upper,10x magnification. Lower, 40x magnification. The sections show a malignant epithelial lesion, made up mostly of papillary structures and a minority of moderately defined follicular structures, lined by cuboidal to columnar cells with the presence of round to oval nuclei, with the presence of nuclear clearance, nuclear inclusions and fissures, adopting an infiltrative pattern.

categorized by thyroid scan; 4 . The diagnosis of thyroid cancer was confirmed in the surgical specimen; 5 . The lesion described as cancer on the surgical specimen corresponds to the hot nodule on the thyroid scan. The exclusion criteria were: CE00: Duplicate documents in databases; CE01: Article that does not address the topic and was conducted in a pediatric population; CE02: Systematic review that does not address the topic; CE03: Meta-analysis study that does not address the topic; CE04: Clinical case that does not address the topic; CE05: Original study that does not address the topic; CE06: Literary or sys- 
tematic review that addresses the topic; CE07: Meta-analysis study addressing the topic.

The application of the inclusion and exclusion criteria during the systematic review process is summarized in figure 5 .

The definition of the variables and data for analysis were extracted from the methodology and results of the articles included in the systematic review. The scintigraphic features of the nodules from which cancer-compatible findings were documented were operationalized as a qualitative, nominal and dichotomous variable; it was categorized into two groups, hot nodule and cold nodule. The type of hyperthyroidism was defined with scintigraphy and was operationalized as a qualitative, nominal and polytomous variable. It was categorized into three groups: toxic nodular goiter, presence of a hot nodule that suppresses
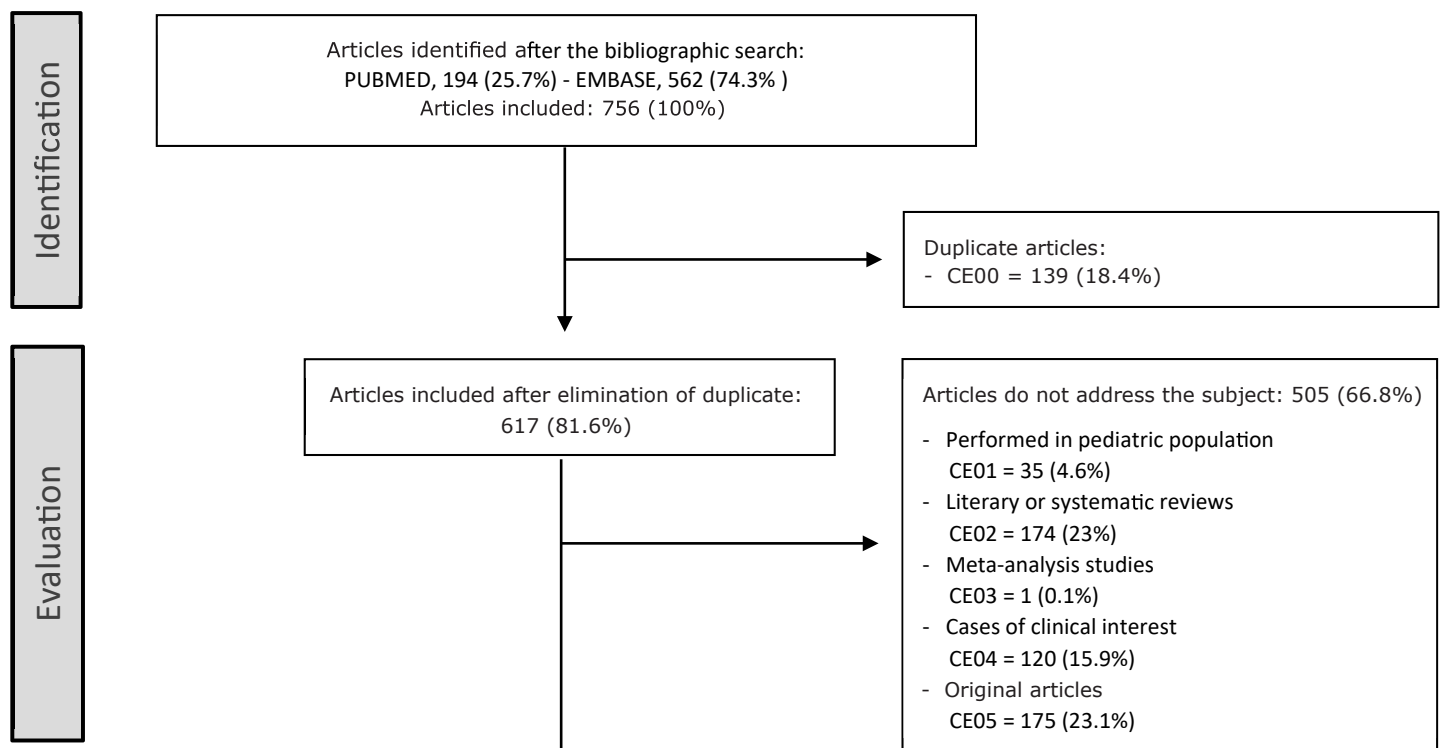

Articles do not address the subject: 505 (66.8\%)

- Performed in pediatric population CE01 $=35(4.6 \%)$

- Literary or systematic reviews CE02 = 174 (23\%)

- Meta-analysis studies $\mathrm{CEO3}=1(0.1 \%)$

- Cases of clinical interest CE04 $=120(15.9 \%)$

- Original articles CE05 $=175(23.1 \%)$

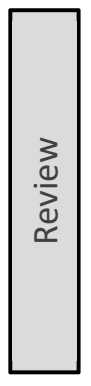

Articles included after review of abstracts: $112(14.8 \%)$

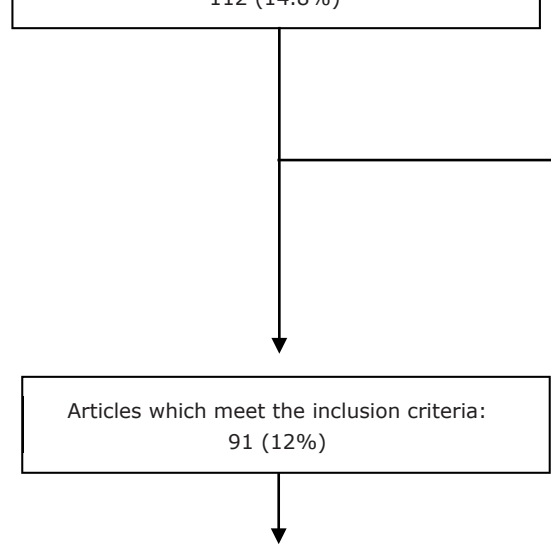

Specimens from patients with cancer and hyperthyroidism $\mathrm{N}=1097$

Figure 1. Sequence of inclusion and exclusion of papers in the systematic review process. 
radiotracer uptake in the rest of the gland; toxic multinodular goiter, presence of one or more hot nodules that do not suppress radiotracer uptake in the rest of the gland; diffuse toxic goiter, presence of diffuse uptake in the gland. In this case the presence of uptake areas greater than the parenchyma uptake were considered as hot nodules, and areas with no uptake were considered as cold nodules. After a bivariate analysis for significance, contrasting the type of hyperthyroidism and the presence or absence of findings compatible with cancer documented from a hot nodule, the variable was dichotomized and categorized as follows: first group, compatible or not compatible with toxic nodular goiter, and second group, compatible or not compatible with toxic diffuse goiter. The histological type was operationalized as a qualitative, ordinal and polytomous variable; it was categorized into five groups: papillary carcinoma, follicular carcinoma, oncocytic carcinoma, anaplastic carcinoma and medullary carcinoma. After a bivariate analysis for significance, contrasting the histological type and the presence or absence of findings compatible with cancer documented from a hot nodule, the variable was dichotomized and categorized into two groups: compatible or not compatible with follicular carcinoma. Tumor size was operationalized as a qualitative, nominal and dichotomous variable; it was categorized into two groups: size $\leq 10 \mathrm{~mm}$ and $>10 \mathrm{~mm}$.

The data extraction process was performed independently, and they were tabulated into two pilot databases. Subsequently, a researcher unified the two databases into a definitive database, and in cases where there was a discrepancy, the data from the corresponding article was extracted and verified by the same author.

\section{Statistical analysis}

The qualitative variables were presented in the form of frequency tables. Prevalence ratio (PR) and odds ratio (OR) were calculated. The statistical significance of this association was calculated using the Pearson Chi-square test. A stratified analysis was performed, adjusting the odds ratio for the diagnosis of a carcinoma from a hot nodule in the group of patients with toxic nodular goiter and toxic diffuse goiter, depending on the histological type and tumor size. The homogeneity of the advantage ratio was calculated by means of the Mantel-Haenszel Chi-square test and the natural logarithm of the effect estimation was used. Effect independence was determined for each of the covariates using the Breslow \& Day statistic. A binary logistic regression model was proposed to predict the probability of making the diagnosis of cancer from a hot nodule based on the type of hyperthyroidism, histological type and tumor size. The variance of the diagnosis of hyperfunctioning carcinoma was evaluated with Negelkerke's $\mathrm{R}^{2}$ model and its statistical significance was assessed using the Hosmer \& Lemeshow statistics. P values less than 0.05 were considered statistically significant. Data analysis was performed with the statistical package IBM SPSS ${ }^{\circledR}$ Statistics 25.0.

\section{Results}

Seven-hundred-fifty-six potentially eligible papers were identified. After applying the exclusion criteria, a total of 91 papers were included ${ }^{5-95}$. The sequence of inclusion and exclusion of articles is summarized in figure 5 .

\section{Inferential Bivariate Analysis}

The prevalence of cancer in hot nodules was statistically higher in specimens with toxic nodular goiter (PR 18.22; 95\% CI 1,567 - 2,119). The probability of identifying cancer in hot nodules in a specimen with toxic nodular goiter was statistically higher (OR 31.00; 95\% CI 18.69 - 51.44). This relationship was statistically significant with a $\mathrm{p}$ value $<0.001$. The prevalence of cancer in hot nodules was statistically lower in specimens with diffuse toxic goiter (PR 0.757; 95\% CI 0.711 - 0.805). The probability of identifying cancer in hot nodules in a specimen with diffuse toxic goiter was statistically lower (OR 0.036; 95\% CI $0.018-0.072$ ). This relationship was statistically significant with a $p$ value $<0.001$. The prevalence of cancer in hot nodules was statistically higher in specimens corresponding to follicular carcinoma (PR 1,592; 95\% CI 1,330-1,906). The probability 
of identifying cancer in hot nodules in a specimen corresponding to follicular carcinoma was statistically higher (OR 10.84; 95\% CI 6.521 - 18.02). The prevalence of cancer in hot nodules was statistically higher for tumor lesions $>10 \mathrm{~mm}$ in size (PR 7.595; 95\% CI 4.097 - 14.08). The probability of identifying cancer in hot nodules in a tumor lesion with size $>10 \mathrm{~mm}$ was statistically higher (OR 8.771; 95\% CI 4.629 - 16.67).

\section{Stratified Inferential Analysis}

The diagnosis compatible with toxic nodular goiter increased the probability of making the diagnosis of cancer in hot nodules independently of the presence or absence of follicular carcinoma as histological type. The increase in the probability of making the diagnosis of hot nodule cancer in the group of patients with and without toxic nodular goiter was heterogeneous depending on the presence or absence of follicular carcinoma as a histological type, and the magnitude of the increase was greater in the group of specimens with follicular carcinoma. The probability of making the diagnosis of cancer in hot nodules was higher in specimens with toxic nodular goiter and follicular carcinoma (OR 3.255; 95\% CI 2.763 - 3.747). This association was statistically significant with a $\mathrm{p}$ value $<0.001$. The diagnosis compatible with toxic nodular goiter increased the probability of making the diagnosis of cancer in hot nodules independently of the presence or absence of a tumor lesion $>10 \mathrm{~mm}$. The increase in the probability of making the diagnosis of cancer in hot nodules in the group of patients with and without toxic nodular goiter was heterogeneous according to the presence or absence of a tumor lesion $>10 \mathrm{~mm}$, and the extent of the increase was greater in the group of specimens with tumor lesions $>10 \mathrm{~mm}$. The probability of making the diagnosis of cancer in hot nodules was higher in specimens with toxic nodular goiter and tumor lesions $>10 \mathrm{~mm}$ (OR 3.343; 95\% CI 2.821 - 3.866). This association was statistically significant with a p value $<0.001$.

The diagnosis compatible with diffuse toxic goiter decreased the probability of making the diagnosis of cancer in hot nodules independently of the presence or absence of a tumor lesion $>10$ $\mathrm{mm}$. The increase in the probability of making the diagnosis of cancer in hot nodules in the group of patients with and without diffuse toxic goiter was heterogeneous according to the presence or absence of a tumor lesion $>10 \mathrm{~mm}$, the extent of the increase was greater in the group of specimens with tumor lesions $>10 \mathrm{~mm}$. The probability of making the diagnosis of cancer in hot nodules was higher in specimens with diffuse toxic goiter and tumor lesions > $10 \mathrm{~mm}$ (OR 0.306, 95\% CI 0.253 - 0.387). This association was statistically significant with a $\mathrm{p}$ value $<0.001$.

\section{Multivariate Inferential Analysis and Binary Logistic Regression Model}

A surgical specimen corresponding to a toxic nodular goiter (OR 6,406; 95\% CI 3,368 - 12,19), a tumor size > $10 \mathrm{~mm}$ (OR 5,524; 95\% CI 2,717 - 11,12), and a histological type compatible with follicular carcinoma (OR 4,678; 95\% CI 2,341 9. 344), independently increased the probability of making the diagnosis of a hot nodule cancer, while a surgical specimen corresponding to a diffuse toxic goiter (OR 0.120; 95\% CI 0.051 - 0.281), independently decreased the probability of making the diagnosis of a hot nodule cancer. This relationship was statistically significant with a $\mathrm{p}$ value $<0.001$. The relationship between the type of hyperthyroidism, histologic type and tumor size, with the prevalence of cancer in hot nodules is summarized in table 1.

The binary logistic regression model built with the independent variables is summarized in table 2. It explains $52 \%$ of the variance in hot nodule cancer diagnosis and correctly classifies $94.1 \%$ of the cases. According to the Hosmer-Lemeshow statistics, this model was statistically significant with a $\mathrm{p}$ value $=0.010$. According to this, the probability that a hyperfunctioning nodule corresponds to a malignant tumor, depending on the presence or absence of the variables included in the model, corresponds to the following equation: $\mathrm{P}=1 /(1+\mathrm{e}-($ LOGIT $)$ where LOGIT $=-1.918+$ (1.857 x toxic nodular goiter $)+(-2.119 \mathrm{x}$ toxic diffuse goiter $)+(1.543 \times$ follicular carcinoma $)+$ (1.707 x diameter $>10 \mathrm{~mm}$ ). 
Table 1. Relationship between the type of hyperthyroidism, histologic type, and nodular size, with the prevalence of thyroid cancer from hot nodules.

\begin{tabular}{|c|c|c|c|c|c|c|c|c|}
\hline & HOT & ODULE & & & & & & \\
\hline & YES $(n=95)$ & $\mathrm{NO}(n=1002)$ & $N=1097$ & $\mathrm{PR}(95 \% \mathrm{Cl})$ & OR $(95 \% \mathrm{Cl})$ & $\mathrm{p} \Omega$ & OR $(95 \% \mathrm{Cl}) \mu$ & $\mathrm{p} \pi$ \\
\hline Toxic nodular goiter & & & & $\begin{array}{c}1.822 \\
(1.567-2.119)\end{array}$ & $\begin{array}{c}31.00 \\
(18.69-51.44)\end{array}$ & 0.000 & $\begin{array}{c}6.406 \\
(3.368-12.19)\end{array}$ & 0.000 \\
\hline Yes & $\begin{array}{c}69 \\
(46.6 \alpha ; 72.6 \beta)\end{array}$ & $\begin{array}{c}79 \\
(53.4 \alpha ; 7.9 \beta)\end{array}$ & $\begin{array}{c}148 \\
(13.5 \beta)\end{array}$ & & & & & \\
\hline No & $\begin{array}{c}26 \\
(2.7 \alpha ; 27.4 \beta)\end{array}$ & $\begin{array}{c}923 \\
(97.3 \alpha ; 92.1 \beta)\end{array}$ & $\begin{array}{c}949 \\
(86.5 \beta)\end{array}$ & & & & & \\
\hline $\begin{array}{l}\text { Toxic multinodular } \\
\text { goiter }\end{array}$ & & & & $\begin{array}{c}0.980 \\
(0.594-1.617)\end{array}$ & $\begin{array}{c}1.023 \\
(0.591-1.772)\end{array}$ & 0.936 & - & - \\
\hline Yes & $\begin{array}{c}17 \\
(8.8 \alpha ; 17.9 \beta)\end{array}$ & $\begin{array}{c}176 \\
(91.2 \alpha ; 17.6 \beta)\end{array}$ & $\begin{array}{c}193 \\
(17.6 \beta)\end{array}$ & & & & & \\
\hline No & $\begin{array}{c}78 \\
(8.6 \alpha ; 82.1 \beta)\end{array}$ & $\begin{array}{c}826 \\
(91.4 \alpha ; 82.4 \beta)\end{array}$ & $\begin{array}{c}904 \\
(82.4 \beta)\end{array}$ & & & & & \\
\hline Toxic diffuse goiter & & & & $\begin{array}{c}0.757 \\
(0.711-0.805)\end{array}$ & $\begin{array}{c}0.036 \\
(0.018-0.072)\end{array}$ & 0.000 & $\begin{array}{c}0.120 \\
(0.051-0.281)\end{array}$ & 0.000 \\
\hline Yes & $\begin{array}{c}9 \\
(1.2 \alpha ; 9.5 \beta)\end{array}$ & $\begin{array}{c}747 \\
(98.8 \alpha ; 74.6 \beta)\end{array}$ & $\begin{array}{c}756 \\
(68.9 \beta)\end{array}$ & & & & & \\
\hline No & $\begin{array}{c}86 \\
(25.2 \alpha ; 90.5 \beta)\end{array}$ & $\begin{array}{c}255 \\
(74.8 \alpha ; 25.4 \beta)\end{array}$ & $\begin{array}{c}341 \\
(31.1 \beta)\end{array}$ & & & & & \\
\hline Follicular carcinoma & & & & $\begin{array}{c}1.592 \\
(1.330-1.906)\end{array}$ & $\begin{array}{c}10.84 \\
(6.521-18.02)\end{array}$ & 0.000 & $\begin{array}{c}4.678 \\
(2.341-9.344)\end{array}$ & 0.000 \\
\hline Yes & $\begin{array}{c}34 \\
(41.0 \alpha ; 36.9 \beta)\end{array}$ & $\begin{array}{c}49 \\
(59.0 \alpha ; 4.8 \beta)\end{array}$ & $\begin{array}{c}83 \\
(7.6 \beta)\end{array}$ & & & & & \\
\hline No & $\begin{array}{c}61 \\
(6.0 \alpha ; 63.1 \beta)\end{array}$ & $\begin{array}{c}953 \\
(94.0 \alpha ; 95.2 \beta)\end{array}$ & $\begin{array}{c}1014 \\
(92.4 \beta)\end{array}$ & & & & & \\
\hline $\begin{array}{l}\text { Nodular } \\
\text { size }>10 \mathrm{~mm}\end{array}$ & & & & $\begin{array}{c}7.595 \\
(4.097-14.08)\end{array}$ & $\begin{array}{c}8.771 \\
(4.629-16.67)\end{array}$ & 0.000 & $\begin{array}{c}5.524 \\
(2.717-11.12)\end{array}$ & 0.000 \\
\hline Yes & $\begin{array}{c}84 \\
(15.3 \alpha ; 88.4 \beta)\end{array}$ & $\begin{array}{c}466 \\
(84.7 \alpha ; 46.5 \beta)\end{array}$ & $\begin{array}{c}550 \\
(50.1 \beta)\end{array}$ & & & & & \\
\hline No & $\begin{array}{c}11 \\
(2.0 \alpha ; 11.6 \beta)\end{array}$ & $\begin{array}{c}536 \\
(98.0 \alpha ; 53.4 \beta)\end{array}$ & $\begin{array}{c}107 \\
(19.5 \beta)\end{array}$ & & & & & \\
\hline
\end{tabular}

( $\alpha$ ) Prevalence as a function of the presence or absence of the independent variable. ( $\beta$ ) Prevalence as a function of the presence or absence of the dependent variable. $(\mu)$ OR adjusted according to multivariate inferential analysis of binary logistic regression. $(\Omega)$ Pearson's

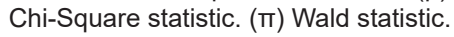

\section{Discussion}

Our revision confirms that in surgical specimens of patients diagnosed with hyperthyroidism and thyroid cancer, most of the malignant tumors derive from a cold nodule. However, $8.6 \%$ of the cases of cancer identified in the present review derived from a hot nodule, which forces us as clinicians to preoperatively rule out the presence of cancer in this group of patients. The proposed binary re- gression model suggested that clinical characteristics such as a clinical diagnosis corresponding to toxic nodular goiter, a histology compatible with follicular carcinoma, and a nodular diameter > $10 \mathrm{~mm}$, on their own, are clinical characteristics capable of increasing the probability that a hot nodule corresponds to a malignant tumor, while a clinical diagnosis corresponding to diffuse toxic goiter decreases this probability. 
Table 2. Probability of diagnosing a malignant tumor from a hot nodule according to the binary logistic regression model, $\mathrm{P}=1 /(1+\mathrm{e}-(\mathrm{LOGIT}))$, where LOGIT $=-1,918+(1,857 \mathrm{x}$ toxic nodular goiter $)+(-2,119 \mathrm{x}$ toxic diffuse goiter $)$ $+(1,543 \times$ follicular carcinoma $)+(1,707 \times$ diameter $>10 \mathrm{~mm})$. $\alpha)$ Frequency according to the group of cold nodules and hot nodules. $(\beta)$ Frequency as a function of the study population.

\begin{tabular}{cccccccc}
\hline Group & $\begin{array}{c}\text { Type of } \\
\text { Hyperthyroidism }\end{array}$ & $\begin{array}{c}\text { Follicular } \\
\text { Carcinoma }\end{array}$ & $\begin{array}{c}\text { Nodular } \\
\text { Size }\end{array}$ & $\begin{array}{c}\text { Hot Nodule } \\
\mathbf{n}(\%)\end{array}$ & $\begin{array}{c}\text { Probability } \\
(\mathbf{p})\end{array}$ & $\begin{array}{c}\text { Cold Nodule } \\
\mathbf{n}(\%)\end{array}$ & $\begin{array}{c}\text { Probability } \\
(\mathbf{p})\end{array}$ \\
\hline 1 & Toxic nodular goiter & Compatible & $>10 \mathrm{~mm}$ & $31(32.6 \alpha ; 2.8 \beta)$ & 0,815 & $1(0.1 \alpha ; 0.1 \beta)$ & 0,185 \\
2 & Toxic nodular goiter & Incompatible & $>10 \mathrm{~mm}$ & $35(36.8 \alpha ; 3.2 \beta)$ & 0,485 & $40(4.0 \alpha ; 3.6 \beta)$ & 0,515 \\
3 & Toxic nodular goiter & Compatible & $\leq 10 \mathrm{~mm}$ & $2(2.1 \alpha ; 0.2 \beta)$ & 0,444 & $0(0.0 \alpha ; 0.0 \beta)$ & 0,556 \\
4 & Toxic multinodular goiter & Compatible & $>10 \mathrm{~mm}$ & $1(1.1 \alpha ; 0.1 \beta)$ & 0,407 & $11(1,1 \alpha ; 1.0 \beta)$ & 0,593 \\
5 & Toxic nodular goiter & Incompatible & $\leq 10 \mathrm{~mm}$ & $1(1.1 \alpha ; 0.1 \beta)$ & 0,146 & $38(3.8 \alpha ; 3.5 \beta)$ & 0,854 \\
6 & Toxic multinodular goiter & Incompatible & $>10 \mathrm{~mm}$ & $13(13.7 \alpha ; 1.2 \beta)$ & 0,128 & $42(3.5 \alpha ; 3.8 \beta)$ & 0,872 \\
7 & Toxic multinodular goiter & Compatible & $\leq 10 \mathrm{~mm}$ & $0(0.0 \alpha ; 0.0 \beta)$ & 0,111 & $2(0.2 \alpha ; 0.2 \beta)$ & 0,889 \\
8 & Toxic diffuse goiter & Compatible & $>10 \mathrm{~mm}$ & $0(0.0 \alpha ; 0.0 \beta)$ & 0,076 & $23(2.3 \alpha ; 2.1 \beta)$ & 0,924 \\
9 & Toxic multinodular goiter & Incompatible & $\leq 10 \mathrm{~mm}$ & $3(3.2 \alpha ; 0.3 \beta)$ & 0,026 & $105(10.5 \alpha ; 9.6 \beta)$ & 0,974 \\
10 & Toxic diffuse goiter & Incompatible & $>10 \mathrm{~mm}$ & $4(4.2 \alpha ; 0.4 \beta)$ & 0,017 & $333(33.2 \alpha ; 30.4 \beta)$ & 0,983 \\
11 & Toxic diffuse goiter & Compatible & $\leq 10 \mathrm{~mm}$ & $0(0.0 \alpha ; 0.0 \beta)$ & 0,015 & $12(1.2 \alpha ; 1.1 \beta)$ & 0,985 \\
12 & Toxic diffuse goiter & Incompatible & $\leq 10 \mathrm{~mm}$ & $5(5.3 \alpha ; 0.5 \beta)$ & 0,003 & $379(37.8 \alpha ; 34.5 \beta)$ & 0,997 \\
\hline
\end{tabular}

Regarding the histological subtype, the results suggest that the prevalence of follicular carcinoma increases up to $41 \%$ (OR 4.678; $95 \%$ CI 2.341 - 9. 344) when it is calculated from the group corresponding to hot nodules. However, is important the fact that $63 \%$ of the hot nodules, almost two thirds of this group, corresponded to a papillary carcinoma, reason for which a slight increase in the finding of follicular carcinoma in hot nodules is suggested, compared to the usual presentation of the same in nodules in general, therefore this characteristic could be proposed as a possible risk factor between both variables in future studies.

In order to give clinical applicability to this model, it is important to clarify the possibility of documenting these characteristics preoperatively. Thus, the thyroid scan would allow the categorization of patients according to the probable etiology of hyperthyroidism, in addition to documenting the distribution of hot and cold nodules; the thyroid ultrasound would allow the determination of the diameter of the nodular lesions and categorize them as $\leq 10 \mathrm{~mm}$ and $>10 \mathrm{~mm}$. However, it is not possible to determine preoperatively that the histological type corresponds to a follicular carcinoma, because the cytology obtained by fine needle puncture is not capable of preoperatively diagnosing this tumor lesion ${ }^{96,97}$. As a clinical alternative there is the option of categorizing patients according to the presence or absence of nuclear changes compatible with follicular neoplasia in the cytological smear.

As described in table 2, it is possible to suggest that patients with the factors corresponding to group 1 have the highest probability that a hot nodule corresponds to a malignant tumor; similarly, patients with the factors corresponding to group 12 have the highest probability that a cold nodule corresponds to a malignant tumor. The probability attributable to the diagnosis of cancer from hot nodules for the rest of the group should be applied according to the clinical context of each patient, and in particular, in patients with 
characteristics corresponding to group 7, group 8 , and group 11, the probabilities calculated from the regression model are not clinically applicable, which is justified in that no cases of cancer from hot nodules were documented in these groups.

The methodological attributes that support our binary logistic regression model are subject to selection biases, as the data used in the statistical analysis corresponded to a tertiary sources. Therefore, we invite the academic community to carry out prospective studies, in which it is verified that the prevalences and probabilities exposed in the present model correspond to the real clinical observations, where homogeneous measurement of the factors described can be performed, and propose other possible clinical characteristics that can be associated to the diagnosis of cancer in hot nodules.

\section{Conclussion}

The possibility of diagnosing a malignant tumor from a hot nodule must be taken into account in clinical practice. The clinical diagnosis corresponding to toxic nodular goiter, a histology compatible with a follicular carcinoma, and a nodular diameter $>10 \mathrm{~mm}$, on their own, are clinical characteristics capable of increasing the probability that a hot nodule corresponds to a malignant tumor. Prospective studies should be conducted to evaluate the clinical characteristics described here, and to propose other possible factors associated with the diagnosis of cancer derived from hot nodules.

\section{Compliance with ethical standards}

Informed consent: Informed consent was required to present the clinical history and images corresponding to the clinical case.

Conflict of interest: The authors have no conflict of interest to declare.

Funding sources: This research project was funded by the Vice-Rectory for Research of the University of Cartagena, it was developed within the framework of the Strengthening Plan of the Scalpellum Research Group. Act of Commitment No. 066 of 2019 and Resolution No. 01430 of 2019.

\section{Authors' contributions:}

Conception and design of the study: Carlos Osorio, Jorge Ballestas.
Data acquisition: Jorge Ballestas, Andrés Arevalo, Shekyna Montaño, Nashelly Perez, Yessica Guardo, Hernán Oviedo, Valeria Zambrano, Diego Barrios.

Data analysis and interpretation: Carlos Osorio.

Drafting the manuscript: Carlos Osorio, Jorge Ballestas.

Critical review: Carlos Osorio, Katherine Redondo, Francisco Herrera.

\section{References}

1. Haugen BR, Alexander EK, Bible KC, Doherty GM, Mandel SJ, Nikiforov YE, et al. 2015 American Thyroid Association Management Guidelines for Adult Patients with Thyroid Nodules and Differentiated Thyroid Cancer: The American Thyroid Association Guidelines Task Force on Thyroid Nodules and Differentiated Thyroid Cancer. Thyroid. 2016;26:1-133.

https://doi.org/10.1089/thy.2015.0020

2. Pazaitou-Panayiotou K, Michalakis K, Paschke R. Thyroid cancer in patients with hyperthyroidism. Horm Metab Res. 2012;44:255-62. https://doi.org/10.1055/s-0031-1299741

3. Liu J, Wang Y, Da D, Zheng M. Hyperfunctioning thyroid carcinoma: A systematic review. Mol Clin Oncol. 2019;11:535-50.

https://doi.org/10.3892/mco.2019.1927

4. Liberati A, Altman DG, Tetzlaff J, Mulrow C, Gøtzsche PC, Ioannidis JP, et al. The PRISMA statement for reporting systematic reviews and meta-analyses of studies that evaluate health care interventions: explanation and elaboration. PLoS Med. 2009;6:e1000100.

https://doi.org/10.1371/journal.pmed.1000100

5. Bitton RN, Sachmechi I, Tabriz MS, Murphy L, Wasserman P. Papillary carcinoma of the thyroid with manifestations resembling Graves' disease. Endocr Pract. 2001;7:106-9. https://doi.org/10.4158/EP.7.2.106

6. Mazziotti G, Rotondi M, Manganella G, Franco R, Capone PF, Colantuoni V, et al. Medullary thyroid cancer, papillary thyroid microcarcinoma and Graves' disease: an unusual clinical coexistence. J Endocrinol Invest. 2001;24:892-966. https://doi.org/10.1007/BF03343948

7. Mishra A, Mishra SK. Thyroid nodules in Graves' disease: implications in an endemically iodine deficient area. J Postgrad Med. 2001;47:244-7.

8. Als C, Gedeon P, Rösler H, Minder C, Netzer P, Laissue JA. Survival analysis of 19 patients with toxic thyroid carcinoma. J Clin Endocrinol Metab. 2002;87:4122-7. https://doi.org/10.1210/jc.2001-011147

9. Basaria S, Salvatori R. Thyrotoxicosis due to metastatic papillary thyroid cancer in a patient with Graves' disease. J Endocrinol Invest. 2002;25:639-42. https://doi.org/10.1007/BF03345090 
10. Harach HR, Sánchez SS, Williams ED. Pathology of the autonomously functioning (hot) thyroid nodule. Ann Diagn Pathol. 2002;6:10-19. https://doi.org/10.1053/adpa.2002.30605

11. Newman SL, Griffith AY, Herbst AB, Yeh IT, Kukora JS. An unusual initial manifestation of metastatic papillary thyroid carcinoma: radioiodine uptake in lymph node metastatic lesions in a patient with Graves' disease. Endocr Pract. 2002;8:304-6. https://doi.org/10.4158/EP.8.4.304

12. Stocker DJ, Foster SS, Solomon BL, Shriver CD, Burch HB. Thyroid cancer yield in patients with Graves' disease selected for surgery on the basis of cold scintiscan defects. Thyroid. 2002;12:305-11. https://doi.org/10.1089/10507250252949432

13. Villar A, Zurro J, De Luis DA, Cuéllar L, Terroba C, Romero E. Acromegalia, bocio tóxico multinodular y carcinoma papilar de tiroides, probable papel de las proteínas G. An Med Interna. 2002;19:37-8. https://doi.org/10.4321/S0212-71992002000200007

14. Yaturu S, Fowler MR. Differentiated thyroid carcinoma with functional autonomy. Endocr Pract. 2002;8:36-9. https://doi.org/10.4158/EP.8.1.36

15. dell'Erba L, Gerundini P, Caputo M, Bagnasco M. Association of hyperfunctioning thyroid adenoma with thyroid cancer presenting as "trapping only" nodule at 99mTc04- scintigraphy. J Endocrinol Invest. 2003;26:1124-7. https://doi.org/10.1007/BF03345262

16. Führer D, Tannapfel A, Sabri O, Lamesch P, Paschke R. Two somatic TSH receptor mutations in a patient with toxic metastasising follicular thyroid carcinoma and non-functional lung metastases. Endocr Relat Cancer. 2003;10:591-600.

https://doi.org/10.1677/erc.0.0100591

17. Gabriele R, Letizia C, Borghese M, De Toma G, Celi M, Izzo L, et al. Thyroid cancer in patients with hyperthyroidism. Horm Res. 2003;60:79-83. https://doi.org/10.1159/000071875

18. Gerenova J, Buysschaert M, de Burbure CY, Daumerie C. Prevalence of thyroid cancer in Graves' disease: a retrospective study of a cohort of 103 patients treated surgically. Eur J Intern Med. 2003;14:321-5. https://doi.org/10.1016/S0953-6205(03)00105-5

19. Lin C, Chiang F, Wang L. Prevalence of thyroid cancer in hyperthyroidism treated by surgery. Kaohsiung J Med Sci. 2003;19:379-384. https://doi.org/10.1016/S1607-551X(09)70480-2

20. Wong CP, AuYong TK, Tong CM. Thyrotoxicosis: a rare presenting symptom of Hurthle cell carcinoma of the thyroid. Clin Nucl Med. 2003;28:803-6.

https://doi.org/10.1097/01.rlu.0000089667.15648.e9

21. Gozu H, Avsar M, Bircan R, Sahin S, Ahiskanali R, Gulluoglu B, et al. Does a Leu 512 Arg thyrotropin receptor mutation cause an autonomously functioning papillary carcinoma?. Thyroid. 2004;14:975-80. https://doi.org/10.1089/thy.2004.14.975
22. Majima T, Doi K, Komatsu Y, Itoh H, Fukao, Shigemoto M, et al. Papillary thyroid carcinoma without metastasis manifesting as an autonomously funtioning thyroid nodule. Endocrin J. 2005;52:309-16. https://doi.org/10.1507/endocrj.52.309

23. Sahin M, Guvener ND, Ozer F, Sengul A, Ertugrul D, Tutuncu NB. Thyroid cancer in hyperthyroidism: incidence rates and value of ultrasound-guided fine-needle aspiration biopsy in this patient group. J Endocrinol Invest. 2005;28:815-8. https://doi.org/10.1007/BF03347572

24. Taneri F, Kurukahvecioglu O, Ege B, Yilmaz U, Tekin EH, Cifter C, et al. Clinical presentation and treatment of hyperthyroidism associated with thyroid cancer. Endocr Regul. 2005;39:91-6.

25. Bitterman A, Uri O, Levanon A, Baron E, Lefel O, Cohen 0 . Thyroid carcinoma presenting as a hot nodule. Otolaryngol Head Neck Surg. 2006;134:888-9. https://doi.org/10.1016/j.otohns.2005.03.054

26. Cappelli C, Braga M, De Martino E, Castellano M, Gandossi E, Agosti B, et al. Outcome of patients surgically treated for various forms of hyperthyroidism with differentiated thyroid cancer: experience at an endocrine center in Italy. Surg Today. 2006;36:125-30. https://doi.org/10.1007/s00595-005-3115-3.

27. Niepomniszcze H, Suárez H, Pitoia F, Pignatta A, Danilowicz K, Manavela M, et al. Follicular carcinoma presenting as autonomous functioning thyroid nodule and containing an activating mutation of the TSH receptor (T620I) and a mutation of the Ki-RAS (G12C) genes. Thyroid. 2006;16:497-503. https://doi.org/10.1089/thy.2006.16.497

28. Ohno S, Yamamoto N, Asato R, Tanaka S, Ito J, Omori K, et al. Functioning Thyroid Papillary Carcinoma: A case report. Practica Oto-Rhino-Laryngologica. 2006;99:43-7. https://doi.org/10.5631/jibirin.99.43

29. Pucci A, Suppo M, Lucchesi G, Celeste A, Viberti L, Pellerito R, et al. Papillary thyroid carcinoma presenting as a solitary soft tissue arm metastasis in an elderly hyperthyroid patient. Case report and review of the literature. Virchows Arch. 2006;448:857-61. https://doi.org/10.1007/s00428-006-0187-4

30. Weber KJ, Solorzano CC, Lee JK, Gaffud MJ, Prinz RA. Thyroidectomy remains an effective treatment option for Graves' disease. Am J Surg. 2006;191:400-5. https://doi.org/10.1016/j.amjsurg.2005.10.043

31. Cakir M, Arici C, Alakus H, Altunbas H, Balci MK, Karayalcin U. Incidental thyroid carcinoma in thyrotoxic patients treated by surgery. Horm Res. 2007;67:96-9. https://doi.org/10.1159/000096357

32. Casañ R, Gómez M, García K, Yanini J, Peña H, Muñoz ML, et al. Características clínicas, histológicas y evolutivas de una serie de 11 casos de cáncer diferenciado de tiroides con hipertiroidismo. Endocrinol Nutr. 2007;54:134-8. https://doi.org/10.1016/S1575-0922(07)71421-3 
33. Cerci C, Cerci SS, Eroglu E, Dede M, Kapucuoglu N, Yildiz M, Bulbul M. Thyroid cancer in toxic and non-toxic multinodular goiter. J Postgrad Med 2007;53:157-60. https://doi.org/10.4103/0022-3859.33855

34. Kim TS, Asato R, Akamizu T, Harada D, Nakashima Y, Higashi T, et al. A rare case of hyperfunctioning papillary carcinoma of the thyroid gland. Acta Otolaryngol. 2007;127:55-7. https://doi.org/10.1080/03655230601066785

35. Makarewicz J, Mikosiński S, Rutkowski A, Adamczewski Z, Lewiński A. Graves' thyrotoxicosis in a patient with metastatic differentiated thyroid carcinoma and chronic lymphocytic leukaemia. Arch Med Sci. 2007;3: 179-84.

36. Yano Y, Shibuya H, Kitagawa W, Nagahama M, Sugino $\mathrm{K}$, Ito K, et al. Recent outcome of Graves' disease patients with papillary thyroid cancer. Eur J Endocrinol. 2007;157:325-9. https://doi.org/10.1530/EJE-07-0136

37. Cross GA, Suarez H, Pitoia F, Moncet D, Venegas M, Niepomniszcze, et al. Fatal outcome of a young woman with papillary thyroid carcinoma and graves' disease: possible implication of "cross-signalling" mechanism. Arq Bras Endocrinol Metabol. 2008;52:1194-200. https://doi.org/10.1590/S0004-27302008000700018

38. Dănilă R, Karakas E, Osei-Agyemang T, Hassan I. Outcome of incidental thyroid carcinoma in patients undergoing surgery for Graves' disease. Rev Med Chir Soc Med Nat Iasi. 2008;112:115-8.

39. Erbil Y, Barbaros U, Ozbey N, Kapran Y, Tükenmez M, Bozbora A, et al. Graves' disease, with and without nodules, and the risk of thyroid carcinoma. J Laryngol Otol. 2008;122:291-5. https://doi.org/10.1017/S0022215107000448

40. Mssrouri R, Benamr S, Essadel A, Mdaghri J, Mohammadine E, Lahlou $\mathrm{M}$, et al. Maladie de Basedow et cancers différenciés de la thyroïde. J Chir. 2008;145:244-6. https://doi.org/10.1016/S0021-7697(08)73753-0

41. Nishida AT, Hirano S, Asato R, Tanaka S, Kitani Y, Honda $\mathrm{N}$, et al. Multifocal hyperfunctioning thyroid carcinoma without metastases. Auris Nasus Larynx. 2008;35:432-6. https://doi.org/10.1016/j.anl.2007.07.008

42. Phitayakorn R, McHenry C. Incidental thyroid carcinoma in patients whit Graves' disease. AJS. 2008;195:292-7. https://doi.org/10.1016/j.amjsurg.2007.12.006

43. Senyurek Giles Y, Tunca F, Boztepe H, Kapran Y, Terzioglu T, Tezelman S. The risk factors for malignancy in surgically treated patients for Graves' disease, toxic multinodular goiter, and toxic adenoma [published correction appears in Surgery. 2009 Sep;146:482.

44. Uludag M, Yetkin G, Citgez B, Isgor A, Basak T. Autonomously functioning thyroid nodule treated with radioactive iodine and later diagnosed as papillary thyroid cancer. Hormones. 2008;7:175-9. https://doi.org/10.1007/BF03401510
45. Basu S, Moghe SH, Shet T, Borges AM. A nonpalpable toxic thyroid lobe besides a malignant lobe. Hell J Nucl Med. 2009;12:173-4.

46. Wang CY, Chang TC. Toxic nodular goiter with thyroid papillary microcarcinoma. ANZ J Surg. 2010;80:117. https://doi.org/10.1111/j.1445-2197.2009.05193.x

47. Azevedo MF, Casulari LA. Hyperfunctioning thyroid cancer: a five-year follow-up. Arq Bras Endocrinol Metabol. 2010;54:78-80. https://doi.org/10.1590/S0004-27302010000100013

48. Bommireddipalli S, Goel S, Gadiraju R, Paniz-MondolFi A, DePuey EG. Follicular variant of papillary thyroid carcinoma presenting as a toxic nodule by I-123 scintigraphy. Clin Nucl Med. 2010;35:770-5. https://doi.org/10.1097/RLU.0b013e3181e4dc7f

49. Giovanella L, Fasolini F, Suriano S, Mazzucchelli L. Hyperfunctioning solid/trabecular follicular carcinoma of the thyroid gland. J Oncol. 2010;2010:635984. https://doi.org/10.1155/2010/635984

50. Hernán-Martínez J, Uzcategui M, Corder E, Castillo M, Sostre S, Alicea L. Hyperthyroidism, hyperfunctioning thyroid nodule, and thyroid cancer in a young female: a rare and unusual coexistence. P R Health Sci J. 2010;29:78-82.

51. Nunes Vdos S, Tagliarini JV, Marques ME, de Godoi JA, Mazeto GM. A patient with Graves' disease and three types of thyroid carcinoma. Thyroid. 2010;20:573-4. https://doi.org/10.1089/thy.2008.0330

52. Tfayli HM, Teot LA, Indyk JA, Witchel SF. Papillary thyroid carcinoma in an autonomous hyperfunctioning thyroid nodule: case report and review of the literature. Thyroid. 2010;20:1029-32. https://doi.org/10.1089/thy.2010.0144

53. Berker D, Isik S, Ozuguz U, Tutuncu Y, Kucukler K, Akbaba G, et al. Prevalence of incidental thyroid cancer and its ultrasonographic features in subcentimeter thyroid nodules of patients with hyperthyroidism. Endocr. 2011;39:13-20. https://doi.org/10.1007/s12020-010-9405-6

54. Ciarallo A, Makis W, Novales-Diaz JA. Incidental papillary thyroid carcinoma in a patient presenting with Graves' hyperthyroidism and concomitant obstructive sequestered intrathoracic multinodular goiter. Clin Nucl Med. 2011;36:145-7. https://doi.org/10.1097/RLU.0b013e318203bcc6

55. Polyzos SA, Goulis DG. Coincidental thyroid papillary microcarcinoma in a patient treated for a toxic adenoma of the thyroid. Arch Iran Med. 2011;14:149-51.

56. Yalla NM, Reynolds LR. Hürthle cell thyroid carcinoma presenting as a "hot" nodule. Endocr Pract. 2011;17:e68-e72. https://doi.org/10.4158/EP10334.CR

57. Zivaljevic V, Zivic R, Diklic A, Krgovic K, Kalezic N, Vekic $B$, et al. Unifokale hyperfunktionelle Karzinome der Schilddrüse [Solitary hyperfunctioning thyroid gland carcinomas]. Zentralbl Chir. 2011;136:374-8. https://doi.org/10.1055/s-0030-1262541 
58. Karanchi H, Hamilton DJ, Robbins RJ. Hürthle cell carcinoma of the thyroid presenting as thyrotoxicosis. Endocr Pract. 2012;18:e5-e9. https://doi.org/10.4158/EP11142.CR

59. Nair CG, Jacob P, Babu M, Menon R. Toxic thyroid carcinoma: A new case. Indian J Endocrinol Metab. 2012;16:668-70. https://doi.org/10.4103/2230-8210.98047

60. Polat SB, Er M, Önal ED, Ersoy R, Çakır B. Graves' Disease and Papillary Thyroid Carcinoma in a Patient with Active Sarcoidosis. Türk Jem. 2012;16:72-4. https://doi.org/10.4274/Tjem.2042

61. Rehman RA, Nyenwe E. Papillary thyroid carcinoma in a toxic adenoma. JIM. 2012;60:350-1.

62. Resch T, Sucher R, Wimmer G, Hauck A, Fussenegger $D$, Stromberger K, et al. Is Grave's disease a risk factor for thyroid carcinoma?. Eur Surg. 2012;44:104.

63. Anastasilakis AD, Ruggeri RM, Polyzos SA, Makras P, Molyva D, Campennì A, et al. Coexistence of Graves' disease, papillary thyroid carcinoma and unilateral benign struma ovarii: case report and review of the literature. Metabolism. 2013;62:1350-6. https://doi.org/10.1016/j.metabol.2013.05.013

64. Calimon M, Lim U. Papillary thyroid carcinoma with lymphocytic thyroiditis in an autonomous hyperfunctioning thyroid nodule. Eur Thyroid J. 2013;2:125.

65. Chinchuk I, Sleptsov I, Isheiskaya M, Chernikov R, Semenov A, Makarin V, et al. Thyroid cancer in graves disease patients. Eur Thyroid J. 2013;2:164.

66. Grigorovici A,Velicescu C, Costache M, Ciobanu D. The incidence of thyroid cancer in patients whit Graves' disease. Langenbecks Arch Surg. 2013;398:767.

67. Mirfakhraee S, Mathews D, Peng L, Woodruff S, Zigman JM. A solitary hyperfunctioning thyroid nodule harboring thyroid carcinoma: review of the literature. Thyroid Res. 2013;6:7. https://doi.org/10.1186/1756-6614-6-7

68. Ngalob QG, Isip-Tan IT. Thyroid cancer in Plummer's disease. BMJ Case Rep. 2013;2013:bcr201300890. https://doi.org/10.1136/bcr-2013-008909

69. Pacenza N, Groppo N, Guibourg H. Asociación de carcinoma papilar de tiroides y enfermedad de Graves. Inesperada evolución y eficacia de la dosis ablativa con tirotrofina recombinante humana (rhTSH). Rev Argent Endocrinol Metab. 2013;50:35-41.

70. Ruggeri RM, Campennì A, Giovinazzo S, Saraceno G, Vicchio TM, Carlotta D, et al. Follicular variant of papillary thyroid carcinoma presenting as toxic nodule in an adolescent: coexistent polymorphism of the TSHR and Gs $\alpha$ genes. Thyroid. 2013;23:239-42. https://doi.org/10.1089/thy.2012.0279.

71. Zahn A, Kußmann J. Thyroid cancer in patients with Graves' disease. Langenbecks Arch Surg. 2013; 398:769.

72. Ergin AB, Saralaya S, Olansky L. Incidental papillary thyroid carcinoma: clinical characteristics and prog- nostic factors among patients with Graves' disease and euthyroid goiter, Cleveland Clinic experience. Am J Otolaryngol. 2014;35:784-90. https://doi.org/10.1016/j.amjoto.2014.04.013

73. Gabalec F, Svilias I, Plasilova I, Hovorkova E, Ryska A, Horacek J. Follicular variant of papillary carcinoma presenting as a hyperfunctioning thyroid nodule. J Pediatr Hematol Oncol. 2014;36:e94-e96. https://doi.org/10.1097/MPH.0000000000000036.

74. He Y, Liu S, Guo H, Shi B. Incidental finding of papillary thyroid carcinoma with BRAFV600E mutation in a patient with coexistent primary hyperparathyroidism and Graves' hyperthyroidism. BMJ Case Rep. 2014;2014:bcr2013203436.

https://doi.org/10.1136/bcr-2013-203436

75. Kuan Y, Florence H. Thyroid papillary carcinoma in a "hot" thyroid nodule. Q J Med. 2014;107:475-6. https://doi.org/10.1093/qjmed/hct204

76. Preece J, Grodski S, Yeung M, Bailey M, Serpell J. Thyrotoxicosis does not protect against incidental papillary thyroid cancer. Surgery. 2014;156:1153-6. https://doi.org/10.1016/j.surg.2014.04.025

77. Ren M, Wu MC, Shang CZ, Wang XY, Zhang JL, Cheng H, et al. Predictive factors of thyroid cancer in patients with Graves' disease. World J Surg. 2014;38:80-7. https://doi.org/10.1007/s00268-013-2287-z

78. Tam AA, Kaya C, Kılıç FB, Ersoy R, Çakır B. Thyroid nodules and thyroid cancer in Graves' disease. Arq Bras Endocrinol Metabol. 2014;58:933-8. https://doi.org/10.1590/0004-2730000003569

79. Tamatea JA, Tu'akoi K, Conaglen JV, Elston MS, Meyer-Rochow GY. Thyroid cancer in Graves' disease: is surgery the best treatment for Graves' disease? ANZ J Surg. 2014;84:231-4. https://doi.org/10.1111/j.1445-2197.2012.06233.x

80. Campennì A, Giovinazzo $\mathrm{S}$, Curtò L, Giordano E, Trovato M, Ruggeri RM, et al. Thyroid hemiagenesis, Graves' disease and differentiated thyroid cancer: a very rare association: case report and review of literature. Hormones. 2015;14:451-8. https://doi.org/10.14310/horm.2002.1606

81. Kunjumohamed FP, Al-Busaidi NB, Al-Musalhi HN, Al-Shereiqi SZ, Al-Salmi IS. The prevalence of thyroid cancer in patients with hyperthyroidism. Saudi Med J. 2015;36:874-7. https://doi.org/10.15537/smj.2015.7.11463

82. Padma S, Sundaram PS, Arun BR. Unusual presentation of Warthin variant of Papillary thyroid carcinoma with lymph nodal metastases in a patient of Graves' disease. J Cancer Res Ther. 2015;11:652. https://doi.org/10.4103/0973-1482.138041.

83. Patil M, Kamalanathan S, Sahoo J, Vivekanandan M, Kate V, Pandit N, et al. Papillary thyroid microcarcinoma in Graves' disease presenting as a cystic neck mass. J Cancer Res Ther. 2015;11:986-8. https://doi.org/10.4103/0973-1482.157316 
84. Tastan B, Dogu A, Sevim Y.Thyroid cancer in patients whit hyperthyroidism. WJOES. 2015;7:29-32. https://doi.org/10.5005/jp-journals-10002-1162

85. Wei S, Baloch ZW, LiVolsi VA. Thyroid carcinoma in patients with Graves' disease: an institutional experience. Endocr Pathol. 2015;26:48-53. https://doi.org/10.1007/s12022-014-9343-6

86. Kadia BM, Dimala CA, Bechem NN, Aroke D. Concurrent hyperthyroidism and papillary thyroid cancer: a fortuitous and ambiguous case report from a resource-poor setting. BMC Res Notes. 2016;9:369. https://doi.org/10.1186/s13104-016-2178-0

87. Salih A, Kakamad F, Nihad H. Hyperfunctioning papillary thyroid carcinoma: A case report with literature review. Int J Surg Case Rep. 2016;26:202-4. https://doi.org/10.1016/j.ijscr.2016.08.001

88. Sharma SD, Kumar G, Guner K, Kaddour H. Hyperthyroidism in patients with thyroid cancer. Ear Nose Throat J. 2016;95:236-9. https://doi.org/10.1177/014556131609500612

89. Keskin C, Sahin M, Hasanov R, Aydogan BI, Demir O, Emral R, et al. Frequency of thyroid nodules and thyroid cancer in thyroidectomized patients with Graves' disease. Arch Med Sci. 2019;16:302-7. https://doi.org/10.5114/aoms.2018.81136

90. Lima MJ, Soares V, Koch P, Silva A, Taveira-Gomes A. Autonomously hyperfunctioning cystic nodule harbouring thyroid carcinoma - Case report and literature review. Int J Surg Case Rep. 2018;42:287-9. https://doi.org/10.1016/j.ijscr.2018.01.002

91. Pandey RK, Sharma E, Roy S, Kandel S, Dahal S, Hossain MR, et al. Hot and malignant - a case of invasive papillary carcinoma in hyperthyroid patient with hot nodules. J Community Hosp Intern Med Perspect. 2018;8:220-2.

https://doi.org/10.1080/20009666.2018.1490139
92. Shahbaz A, Fransawy Alkomos M, Mahendhar R, Nabi U, Riaz M, Sachmechi I. Follicular Variant of Papillary Thyroid Carcinoma Presented as Autonomous Functioning Thyroid Nodule: A Case Report and Review of Literature. Cureus. 2018;10:e3014. https://doi.org/10.7759/cureus.3014

93. Punitha S, Vedha pal jeyamani, Sindhu S, Bhuvaneshwari P, Arshath A. Papillary thyroid cancer patient with hyperthyroidism - a case study. Int J Res Pharm Sci. 2019;10:3178-81. https://doi.org/10.26452/ijrps.v10i4.1617

94. Tam AA, Ozdemir D, Alkan A, Yazicioglu O, Yildirim N, Kilicyazgan A, et al. Toxic nodular goiter and thyroid cancer: Is hyperthyroidism protective against thyroid cancer? Surgery. 2019;166:356-61. https://doi.org/10.1016/j.surg.2019.03.012

95. Mintegui G, Saccone S, Mendoza B. Carcinoma tiroideo en nódulo centellográfico hipercaptante: reporte de caso. Rev chil endocrinol diabetes. 2019;12:175-8.

96. Osorio C, Fernández A, Herrera K, Marrugo A, Ensucho C, Redondo K, Herrera F. Sensibilidad y especificidad de la citología obtenida mediante aspiración con aguja fina en el diagnóstico de las neoplasias foliculares de la glándula tiroides: Un estudio prospectivo. Rev Esp Patol. 2016;49:144-50. https://doi.org/10.1016/j.patol.2016.01.005

97. Herrera F, Redondo K, Osorio C, Grice J, Fernández A. Utilidad de la citología obtenida mediante aspiración con aguja fina en el diagnóstico de las neoplasias foliculares de la glándula tiroides en la E.S.E. Hospital Universitario del Caribe: Un estudio retrospectivo. Rev Colomb Cir. 2015;30:12-7. 